\title{
Single-Industry Towns of Russia: Lock-In and Drivers of Innovative Search
}

\author{
Nadezhda Zamyatina \\ Leading Researcher, Faculty of Geography, Lomonosov Moscow State University. Address: Leninskie Gory, \\ GSP-1, 119991 Moscow, Russian Federation. E-mail: nadezam@yandex.ru
}

\begin{abstract}
Alexander Pilyasov
Director, Center for the Northern and Arctic Economies, Council for the Study of Productive Forces. Address: 7 Vavilova str., GSP-7, 177997 Moscow, Russian Federation. E-mail: pelyasov@sops.ru
\end{abstract}

\begin{abstract}
$\mathrm{T}$

he problem of single-industry towns has become increasingly relevant recently in light of the crises in the Russian and global economy. The present article attempts to examine this issue by using methodological approaches adopted internationally to analyse singleindustry towns. At the heart of these approaches is the concept of path dependence, coupled with a method to identify the factors blocking innovative search in the so-called new industrial policy. The authors critically reevaluate the situation in single-industry towns, in contrast to the existing assessments that are widespread in Russian language research. Rather than analysing industrial sectoral specialization, they suggest studying the core of economic

development i.e. a city's capacity to upgrade its local production system and to initiate innovative search.

The article describes the main principles of new industrial policy, which is vulnerable not so much to a narrow specialization but primarily to a package of technological, political, and cognitive lock-ins. These lock-ins prevent the growth of an innovative sector in single-industry towns and stop local communities from being able to adapt to changing economic conditions. The authors show the possibilities and concrete directions of innovative search in various singleindustry towns in Russia. They give recommendations on the key policy instruments that can help overcome the existing lock-ins in monoprofile Russian towns.
\end{abstract}

Keywords: single-industry towns; lock-in in innovative development; innovative search; local community; new industrial policy; entrepreneurship; path dependence

DOI: $10.17323 / 1995-459 X .2016 .3 .53 .64$
Citation: Zamyatina N., Pilyasov A. (2016) Single-Industry Towns of Russia: Lock-In and Drivers of Innovative Search. Foresight and STI Governance, vol. 10, no 3, pp. 53-64.

DOI: 10.17323/1995-459X.2016.3.53.64 


\section{Relevance of studying Single-Industry Towns in modern Russia}

The issue of single-industry towns has been repeatedly addressed in Russia and internationally. At times of crisis, the issue unsurprisingly attracts even more interest. We observe this both in 2008-2009 when the topic was under the radar of the mass media ${ }^{1}$, as well as in the last couple of years when authorities and expert community became genuinely concerned about the problem of single-industry towns ${ }^{2}$ [CISRE, 2012; Lappo, 2012; Lyubovnyi, 2013; BasEl, 2013; VSU, 2013; Pytkin, Zagoruiko, 2011; P'yankova, 2011; Turkov, 2012; Uskova et al., 2012]. A review of the literature shows how the majority of researchers argue that single-industry towns are a legacy of Soviet economic misjudgments; however, this is not completely true. Such towns emerged in Russia not so much because of the economic order of the USSR but mainly because of the industrial era itself, which predetermined the shape of most developed economies. To solve the problem of single-industry towns, it is essential to radically update approaches and modify management strategies rather than their industrial specializations.

The theoretical part of this article compares the results of Russian and international studies on the subject. The array of sources we have analysed includes several dozen Russian and international works (for more detail, see [Zamyatina, Pilyasov, 2015]). The huge number of publications reflects how widespread this phenomenon is: large industrial facilities have become backbone enterprises in hundreds of regions all over the world. Attempts to reform them through dirigiste unified methods with no consideration for local peculiarities have been undertaken not only in Russia. These policies were one-off initiatives such as targeted support of infrastructure projects and the creation of large enterprises (e.g. car plants in coal mining and metallurgical regions) in highly specialized territories. As a rule, such initiatives have been inefficient as they did not solve local problems but only reproduced them. The majority of the more developed economies have gradually switched to a new methodological platform and started to implement approaches that could also be used in Russia despite the latter's specificities. ${ }^{3}$

However, the current state policy and public discussions around single-industry towns in Russia have taken a completely different direction. Calls for direct federal government interventions in social and economic problems of specific cities are heard, while the potential of local communities is underestimated. These are hallmarks of centralized economic policy harmful to development of single-industry territorial entities. International experience shows a contrasting opposite approach is more effective, one focused on fostering innovative search in the towns themselves and enhancing their stability in a changing economic climate. One novel contribution of this article is its theoretical framework of new industrial policy, which remains rarely used by Russian scholars. One of the goals of the present study is to define the principles of this framework and assess how well it can be applied to Russian single-industry towns.

The relevance of modern methods of governing single-industry towns in Russia can be disputed; therefore, we aim to demonstrate how a new industrial policy that relies on local innovative search can be applied in the Russian context. We show that a dismantling of traditional scenarios of development in periphery regions is already underway in single-industry towns of Russia. In seemingly hopeless cases, the local community mobilizes and new drivers of development appear. The paper describes the principles of new industrial policy when applied to Russian single-industry towns, gives specific examples of barriers to their development, and suggests a range of state support measures applicable in current conditions.

\section{Theoretical Assumptions about the Governance of Single-Industry Towns: Innovative Search and New Industrial Policy}

In this paper, innovative search is broadly defined as efforts to select new efficient products, technological processes, and organizational solutions in various economic sectors. This particular set of tools has been suggested by various studies on restructuring single-industry towns as the most efficient long-term strategy [Agrawal et al., 2010; Anas, Xiong, 2005; Bartik, 2009; Caravelis, Russell, 2001; Gebauer et al., 2003; Maier, Trippl, 2011; Todtling, Trippl, 2004; Totzer, Gigler, 2005; Trippl, Otto, 2009].

\footnotetext{
1 On the evolution of views on single-industry towns, see the chapter "Single-Industry Towns Mythology" in [Zubarevich, 2010, pp. 82-96].

2 We specifically mention the first national programme on single-industry towns in CIS countries that was adopted in Kazakhstan by Government Decree \# 683 of 25.05.2012 "On the Adoption of the Single-Industry Towns Development Programme for 2012 2020".

${ }^{3}$ Russia's structural political and economic specificities, including its expansive territory and weak infrastructure, make for more rigid conditions compared to, for example, Europe, and mean Russia is closer to countries such as Brazil and India [Audretsch, Thurik, 2001].
} 
The transition to a new development model is driven by the global context of changing technological patterns and engines of economic growth. The post-industrial economic structure, however, does not suggest that industrial development has to be abandoned, especially in single-industry towns. The industrial sector continues to play an important role in an economy but becomes just one of the elements of the system alongside the local institutional, cultural, entrepreneurial, research, and educational infrastructure. These changes influence industrial policy, which under the new conditions is undergoing a radical transformation, best described by Dani Rodrik in his paper Industrial Policy for the TwentyFirst Century [Rodrik, 2004] and other works [Rodrik, 2008; 2014; Hausmann, Rodrik, 2002; Hausmann et al., 2007]. The elements of new industrial policy may be defined as the focused efforts to establish an environment for the development of industrial enterprises, including the modernization of the education system, promotion of scientific research, support for first-time entrepreneurs (potential suppliers and sub-contractors for large businesses), development of industrial services, and the optimization of the urban environment.

A modern approach to modernizing single-industry and old industrial towns has developed gradually. Globally, namely in the famous German Ruhr region [Hermann, 2002], we can distinguish two stages of restructuring with different ideologies concerning innovative search: in the first stage, such activity does not exist while in the second stage, we see the gradual involvement of local economic agents (Table 1).

As Russia has embarked on transforming single-industry towns much later than the majority of developed countries and still retains features of several various economic set-ups, it is important to introduce new industrial policy methods in the first stage of restructuring. It would be a mistake to wait for the results of a 'natural' evolution of single-industry territorial entities complemented by conventional regulation methods. Why is traditional industrial policy inefficient in the modern context? In virtually all countries, it has been implemented from above through so-called targeting, i.e. the selective support of a sector, industry, or enterprise. The costs of such an approach were arbitrariness in choosing the beneficiaries of state support, large-scale lobbying, and corruption among both public officials distributing state funds and direct recipients of grants, subsidies, and grants.

In the relatively small, Asian economies, the above costs (due to these countries' modest scale and inevitable transparency of disbursement schemes) were marginal compared to the undisputable advantages of boosting new production. In contrast, this traditional policy had in fact discredited itself in European countries. Since the 1980s, European governments began introducing radical market management principles. However, this orthodox liberal approach eventually came into collision with the goals of dynamic development of innovative economic sectors. It became clear that it was impossible to solve the problem of unbalanced regional specializations through purely market mechanisms, hence the aspirations for industrial policy of a different, horizontal type.

The novelty of this policy primarily lies in its orientation towards searching for development opportunities of new types of industrial activities in a given particular territory, rather than direct support tools for sectors and enterprises, such as tax benefits, loans, subsidies or other mechanisms. In such an interpretation, new industrial policy takes a much more holistic form, and its specific efforts often seem unconventional. This refers to policy tools such as subsidizing call centers, tourist or agricultural companies, when these initiatives are aimed at training local entrepreneurs, as well as lowering barriers for local business. Implementing this policy involves not only business and industrial players, but also local authorities, service companies, non-commercial structures, and professional associations.

\section{Table 1. Stages of Single-Industry Towns Restructuring}

\begin{tabular}{|l|l|l|}
\hline \multicolumn{1}{|c|}{ Parameters } & \multicolumn{1}{|c|}{$\begin{array}{c}\text { First 'Inertia' Stage: Surface } \\
\text { Restructuring }\end{array}$} & Second 'Innovative' Stage: Deep Restructuring \\
\hline Innovative search & No & Involves local economic agents \\
\hline Production profile & Preserved and upgraded & $\begin{array}{l}\text { New trends of economic (industrial and } \\
\text { tertiary industry) specializations appear; old } \\
\text { specialization organizationally shrunk and } \\
\text { transformed }\end{array}$ \\
\hline Industrial policy & $\begin{array}{l}\text { Centralized, dirigiste, envisages the } \\
\text { implementation of a common strategy } \\
\text { in all single-industry towns }\end{array}$ & $\begin{array}{l}\text { Decentralized, sensitive to local contexts } \\
\text { in determining new opportunities by local } \\
\text { economic agents }\end{array}$ \\
\hline Support programs & $\begin{array}{l}\text { Major industrial, infrastructure and } \\
\text { educational projects }\end{array}$ & $\begin{array}{l}\text { Network projects on setting up technology } \\
\text { parks, business incubators, innovative clusters, } \\
\text { etc. }\end{array}$ \\
\hline Key problems & $\begin{array}{l}\text { Lock-ins in development - } \\
\text { functional, cognitive, and political }\end{array}$ & Risks and uncertainties \\
\hline Source: compiled by the authors. & \\
\hline
\end{tabular}


The priorities of new industrial policy are therefore defined according to its character: acceleration of innovative processes, promotion of local innovative systems and technological refurbishing of industry, including through external investment and intensifying exports of finished products. The decentralized character of the new industrial policy predefines its deeper local rootedness, based on an understanding of the implicit 'endemic' principles of management and business operations, as well as of local competences. The latter are not so much industry specific but more functional in nature, and aim to, for example, localize imported technologies that are often extremely intensive in terms of time, labour, and resources.

New industrial policy suggests a truly individual approach for each single-industry town. The only common feature of the toolset is the drive to foster innovative search for development opportunities for the town's backbone enterprise, small and medium businesses, and other subjects of the local industrial system. In due course, innovative search results in the selection of institutional practices for attracting investors, implementing projects, and shifting specializations that are efficient for that particular town. It is important to ensure that these positive externalities, new for the town's economy, generate knowledge spillovers, create the conditions for the local community's self-learning, and, moreover, can be easily evaluated in terms of their efficiency.

A modern industrial policy requires the challenges and threats to the sustainable development of singleindustry towns to be reassessed. The methodology of new industrial policy does not see in a narrow specialization or single industry an obstacle, but rather in the specificities of the local environment. Scholars use the notion of path dependence to describe this problem. Production processes and companies' organizational principles, the structure of the urban community, functional space zoning, skills, behavioural models, and the mindsets of the local population are reproduced over many generations and come into conflict with the changing environment, slow down changes, and do not allow new trends to fully emerge. As Douglass North, a Nobel Prize in Economics winner, wrote: 'Path dependence is not "inertia", rather it is the constraints on the choice set in the present that are derived from historical experience of the past" [North, 2005]. Key restructuring problems come down to constraints on choosing ways of development that are generally divided into three groups (types) of so-called lock-ins of innovative development: functional, political, and cognitive [Starodubrovskaya, 2011; Hassink, 2005].

The difference between a typical single-industry town and a locality with similar characteristics but a more diversified profile lies not in the presence of developmental barriers (these exist in all towns) but rather in how much these barriers are expressed. In single-industry mining towns, certain developmental models based on specific resources and operation practices have been established for decades. We typically find firmly held views about conveyor production process and finished product lines that have not changed for many years in these towns. It is not unusual to see families with several generations of workers in them. If the economy is stable, long-term factory traditions ensure greater stability of the production process. Using Mark Granovetter's definition [Granovetter, 1985] this may be called the cultural embeddedness of the local economy. However, with time such embeddedness becomes a constraint as it resists radical innovations and reduces the economy's adaptability to changing market conditions.

These are the negative effects of path dependence. Conservative cultural and behavioural attitudes make it impossible to develop a fresh approach to a town's problems or create demand for change within the local professional community. Instead of launching a process of agile adaptation to current trends and the needed technological and organizational reorganization, people are involved in longstanding discussions about the possibilities for development within the established economic and management paradigm. Ultimately, only a crisis may motivate economic actors, including local authorities, to initiate change based on an extensive innovative search. Getting rid of lock-ins of innovative development could have averted the collapse of many single-industry towns. We now examine in more detail the most characteristic lock-ins.

The greatest challenges generally lie in overcoming cognitive barriers. These are primarily dependency mentalities fostered by a long experience of living in a context of social guarantees offered by a backbone enterprise during its prosperity phase. Such a mentality, on the one hand, stifles individual initiative, in particular that of small business. On the other hand, it decreases the perceived value of activities outside the single-industry town's specialization. A successful backbone enterprise absorbs the most qualified and ambitious young talent, diluting alternative local business and other sectors of the production system.

Political barriers usually consist of passive (and often corrupt) local authorities. This phenomenon is most pronounced when the backbone enterprise belongs to a holding company outside the town. However, the case of Kondopoga and the Kondopoga Pulp and Paper Mill (joint stock company 'Kondopoga') shows that a resident owner may also play a similar negative role in town development. This is especially true for single-industry towns that historically produced goods of national importance: their residents and backbone enterprise workers are accustomed to their own high social standing. 
The former prosperity of the enterprise in Kondopoga resulted in a weak social and political system that manifested itself during the mass riots in 2006. The backbone enterprise used to be the biggest national producer of newsprint paper and owned well-developed social infrastructure. For many years, the factory was headed by the charismatic director, Vitaly Federmesser, who did much to improve urban infrastructure (e.g. paving slabs, fountain, unique carillon bells) and diversify public spaces (e.g. ice arena and arts palace) [KarelInform, 2013]. 'All of these make Kondopoga similar to Moscow Region towns, such as Khimki, Mytishi, Liubertsy, etc.' [Popov, 2007]. However, this company (successful up to the mid-2000s) hindered the development of small and medium enterprises and depleted the labour market by offering prestigious jobs with extremely competitive salaries. Consequently, all powers in the town were accumulated in the hands of the backbone enterprise management. The latter, according to some sources, tried but could not prevent mass disorders, as it did not have the necessary social technologies and was not ready for conflict [Grigoriev, 2006].

Small business development as a resource for economic diversification in such towns is more often than not mere imitation. Dependency mentality not only easily triggers social protests but also blocks preventive actions. In particular, inhabitants of single-industry towns are not usually keen to move to more dynamically developing regions [BazEl, 2013]. They do not even support obvious ways to overcome social tensions, such as offering work in nearby towns when their town's backbone enterprise downsizes.

Pikalyovo became widely known because of the President's intervention in a social and political crisis that broke out in the town. The crisis was provoked not so much by the downsizing policy of the company that owns the backbone enterprise, 'Basic Element', as by the specific behavioural mindsets of the local population. Even before the acute phase of the crisis, unemployed town residents, primarily the younger generation, were offered jobs in other towns, including in a town called Tikhvin located 25 kilometers from Pikalyovo. In some cases, they were even offered higher salaries. The most economically sound solution would be to organize daily transfers to the new place of work. However, local citizens rejected these job offers in other towns en masse, as well as community work and retraining with guaranteed employment. A political way to resolve the conflict prevailed over economic solutions [Dvas, 2009].

The production systems of specific cities have distinct peculiarities, which either aggravate structural constraints on innovative development or mitigate them. Below we summarize these characteristics.

Excessively rigid production chains that decrease the ability of businesses to adapt to changing economic conditions and diversify is a classic problem of Russian single-industry towns. The key root cause for this group of barriers to innovative development is industry profile: the metal and mining industries are least able to diversify and restructure. However, the rigidness of production links usually has a very individual and specific character at each enterprise.

Role of the backbone enterprise in the organizational structure of the company. Independent enterprises with headquarters or core asset business units of a holding company located in the given single-industry town have definite advantages from the point of view of innovative development. In such cases, the enterprise's organizational independence ensures greater flexibility in decision making, research, and resource distribution.

Agglomeration effects occur when a single-industry town is part of an urban agglomeration or is located close to a big regional centre. In such situations, the outcomes of agglomeration effects are negative externalities for the town's production system. Being able to satisfy demand for consumer and business services by a 30-60-minute drive to the nearby big city also hinders internal market development within the single-industry town and ultimately, dispels any trust in the potential for businesses that offer alternatives to the backbone enterprise. Isolation, on the contrary, is often a driver of local economy development, however paradoxical this seems. 
Industry development under unfavourable transport conditions can be illustrated by the case of Kostomuksha. 'A local entrepreneur, Ivan Samokhvalov, explains the reason for setting up local production: "Petrozavodsk is about 500 kilometers away, St Petersburg about 930 kilometers, and the road is very bad at times. When I used to buy sausages in St Petersburg, a car usually arrived here very late at night. In the morning, I had to accept the goods, deliver them to stores, weigh them, and quote a price. Yet the shelf life of French sausages, for example, is 48 hours. So, no sooner had we delivered them, it was time to throw them away. We realized that these products have to be manufactured locally."' [Novikova, 2014; Ekspert Severo-Zapad, 2013]

Agglomeration negatively affects the industrial functions of single-industry towns primarily. A town may survive by becoming a residential, tourist, or even business satellite town. A more comfortable environment in such towns may help them avoid depression and gain competitive advantages: satellite towns are ahead of agglomeration centres thanks to their proximity to nature, human scale of the urban environment, and social infrastructure within walking distance. Hence the creation of a comfortable environment may prove to be the most efficient rehabilitation effort for single-industry towns.

The prevalence of strong social ties, reflected in a lack of trust or even outright hostility to outsiders is one of the typical cognitive barriers to innovative development of single-industry towns. Such barriers rarely play a critical role. They generally occur in the national republics of Russia where they are based on clan social groupings [Humphrey, 2007]. However, strong social ties and a distinction between 'us' and 'them' do remain even in towns with modern management, creating barriers (sometimes of a criminal nature) to local market entry for new players.

\section{We Have Clans in our Town}

The negative influence of social ties on local economic development is clearly illustrated by the following interview: 'In our town, you know, it's like Mafia or Kosa Nostra - we have clans. Whoever works where, the money is shared. Family connections are not as important as business ones. Whom do you consider to be one of "us"? More than that - when children move to Krasnoyarsk it happens that they all live in one district and communicate. ... We do not need you ("them") here. Here, up north, many people try to start a business - this and that is possible - but we won't let them. We don't need you, as you're one of "them".

We won't tolerate any of "them". I for one take and give bribes, and nobody is afraid of taking from me because everybody knows me. Some guys from St. Petersburg came here about eight years ago, they wanted to start a business as the Internet here was crap... They gave away about $\$ 100,000$ in bribes, but all for nothing. I told them: either you make me number one or get the hell outta' here'

Source: interview with an entrepreneur in Dudinka (Krasnoyarsk Krai) taken by one of the authors (N.Z.) in September 2013.

Sometimes, the barriers to business development (including innovative business) created not so much by the inactivity of local authorities but by the opposition of separate groups of businessmen caused by the inefficient organization of social networks. As such, the entrepreneurial energy of the urban community is spent on political infighting at the expense of the actors' economic interests. A classic example from Chicago has been described by the American political scientist Barbara Ferman [Ferman, 1996]. Sometimes, we observe an analogous situation in Russia when the urban community is split due to political activity substituting entrepreneurship.

Often, local specificities facilitate and catalyze innovative search. It is precisely in towns with unique conditions that the local community is more active and new economic and institutional solutions are easier to implement and better perceived locally. These enclaves represent a kind of experimental ground where new approaches to local modernization emerge without direct state support. Innovative search begins under favourable conditions, and then is rolled out as a best practice to other territories with an artificially created environment.

Location on a border or transit route - together with the associated tourist traffic and historical features of the area, etc. - is one of the conditions facilitating the launch of innovative search at a local level. Examples 
of new enterprises in western regions of Karelia that were formerly part of Finland are indicative cases. A familiarity with the area facilitates market entry for Finnish investors and, consequently, almost all European or joint (with Finnish partners) ventures are located in this region of Karelia [RKS Group, 2013; Kospine.Ru, n.d.]. This example proves that external links clearly have a positive influence on the integration of local economic players into global networks. Accordingly, the most important conditions for improving the situation in single-industry towns are their openness, intensification of international economic and information exchange, and incorporation into trans-border social and industrial networks.

Proximity to unique primary resources is an obvious, but not always fully appreciated, advantage for some towns. In the Russian context, this factor becomes critical not so much because of transportation costs but rather because of the chance to have personal control over the production process and reduce the risk of thievery by staff or contractors [Ekspert Severo-Zapad, 2013]. Every single-industry town should be interested in looking for resources (not only primary or natural) that make it an exceptional place. The unique skills and social ties outside the town of the local community that open ways to specific innovations are of utmost importance in this regard. Such search may result in very unusual forms. For example, one could hardly expect that the main source of income for some residents of Baikalsk in Siberia after the closure of their town's backbone enterprise would become selling strawberries first grown commercially by immigrants from Ukraine [CISRE, 2012; Irkutsk Media, 2014].

Strong municipal self-government. The successful extension of an industrial network structure that is responsive to progress and innovations often depends on an efficient leader who is able to mobilize local resources for the development of a remote area. The automotive construction cluster in Kaluga region was built specifically thanks to the authorities' efforts. Many other, less widely known territories, such as Gubkinskiy in Yamalo-Nenets Autonomous Okrug, have similar experiences [Zamyatina, Pilyasov, 2013]. The downsides of strong municipal authorities include excessive influence of some individuals and random factors on drawing up economic and political strategies. Economic growth may slow down significantly when new key decision makers come into the picture or when the conditions of the town's industry structure development changes slightly. To prevent such a scenario, it is possible to initiate institution building in industrial policy. In other words, individuals are substituted as drivers of innovative development at local level by sustainable institutions that specialize in supporting the production and dissemination of innovation, as well as the promotion of networking of market players.

Strengthening local self-government and, most importantly, the involvement of local community in designing economic development strategies and expanding the dialogue between authorities, businesses, and NGOs representatives are cornerstones of single-industry towns' sustainability. Not incidentally, the experiences of reviving the most depressive and crisis-ridden single-industry towns globally involve working with local communities and opinion leaders, and organizing public discussions on proposed developmental scenarios. It is precisely the local community, and not abstract indicators, that determines the destiny of single-industry territories, including making radical decisions such as liquidation or socalled 'controlled shrinking' of a town.

A universal formula for local industry recovery is by improving the political, social, and economic environment. Although the link between these processes may seem questionable, longstanding sustainable changes become possible when their interconnections are taken into account.

\section{New Industrial Policy Tools: Key Recommendations}

Successful economic restructuring of single-industry towns requires the collective actions of authorities, businesses, and the local community. This is typically underestimated, with preference given to issues of budgeting, investment, and infrastructure development. At best, such collective action is mentioned in a declarative manner. However, these declarations remain abstract if one does not accept that the consolidation of efforts of all local economy actors is possible around a specific project, and its individual outcomes may vary a lot. For instance, projects promoting the social responsibility of local businesses may have not just vague charitable goals, but be targeted to creating new points of growth in the local social, cultural, leisure, and other sectors.

Thus, the greatest chances for success of projects aimed at reviving the economy of single-industry towns are those implemented jointly, by pooling resources. This requires efficient communication between authorities and businesses, accountability of the former to the local community, close interaction between producers, alignment of development strategies of different sectors of the municipal economy, as well as sustainable growth of knowledge and competences. Improving transport routes, communication infrastructure, and expanding the channels of integration of single-industry towns into the global information space are technical requirements for opening up local economies. 
The case of Kiruna in Sweden is worth mentioning: the restructuring of the 'LKAB' backbone enterprise is included in a town planning policy that envisages the gradual relocation of a residential area [Chirkova, 2011]. It is noteworthy that the company lists transformation of the urban environment among its key strategic focus areas on its website [LKAB, n.d.].

In many countries, restructuring of single-industry towns is usually performed with the extensive involvement of local businesses, led by a group of innovative entrepreneurs. The latter open up new manufacturing niches and areas, and discover through experimentation promising opportunities for modifying the local specialization based on their given town's specific economic and geographic location, existing natural resources, material assets, and human capital. Entrepreneurs' creativity, as well as their readiness and capabilities for innovative search are generally boosted during times of crisis.

The case of the construction of a bridge across the Saryinka River in the town of Sharya, Kostroma region in Western Russia is an outstanding example of innovative search and local community involvement inspired by complicated social and economic conditions. One of the residential neighbourhoods was cut off from the town centre by the poor state of the old bridge. The residents, abandoning all hopes of getting help from the local administration, raised money for the new bridge themselves. This urgent need consolidated the community: many residents donated money to solve the problem, others purchased materials or personally participated in the construction process. The municipal administration provided some machinery needed for the construction. As material resources were limited, unconventional solutions were found: instead of an expensive crane, the builders used a large-tonnage railway jack owned by a local pensioner. The grassroots initiative dramatically decreased project costs from the initially estimated RUB 13 million to RUB500,000 [Trukhanova, 2013].

The ability to capitalize on local culture, history, traditions, etc. plays an important role in moving from a firmly established pattern of a single-industry town to a more dynamic one, in shifting from an inert state to a creative one. This process is usually described as 'rebranding' or changing the town's image and its conception of development.

The most remarkable and well-known example of rethinking the model of urban economic development is the transformation of Bilbao - an old industrial centre in northern Spain - after the opening of the Guggenheim Museum. The museum's daring building in the Deconstructivist style designed by the outstanding architect Frank Gehry has transformed collective perceptions of the city: from a centre of iron industry, it has become one of the world's Meccas of modern art and tourism [Lee, 2007].

However, the example of Canada's Dawson is more relevant for Russia. The capital of the 'gold rush', made famous by the novels of Jack London, has nowadays almost lost its former meaning and become a thematic tourist attraction. Interest in the town is stirred up by a continuous sequence of events expertly built into the annual calendar - from ice hockey tournaments and the spring carnival to bikers' parades and vaudeville shows [DawsonCity.Ca, n.d.]. The transition from an industrial to cultural specialization is generally accompanied by a sharp population decrease. However, the town itself, its landscape and history are preserved. The town of Dawson is located in a remote area similar to many isolated towns in Russia's Far North. Together with other similar small industrial towns on the periphery, Dawson may set an example for dozens of Russian settlements that have lost their industry but have preserved, at least partially, their cultural heritage coming from the heroic deeds of the construction workers of the first five-year plans, the dedication of the Komsomol brigades doing construction projects, the romantic hardships of Arctic exploration, stories of gold-diggers in Siberia, and space and atomic projects. These territories can and should switch from being depressed areas to becoming tourist centres for preserving the history and collective memory of Russia. 
From a management perspective, the rehabilitation of Russian single-industry towns may take a variety of forms: state programmes for setting up technology parks, supporting local entrepreneurs and developing energy efficient technologies; grants to individual producers or academic institutions; and consultations for local administrations by NGOs (similar to the grant programmes of Opora Rossii for city branding; for example, the town of Kostomuksha in Karelia won Opora's first competition in 2014). The most efficient federal policies seem to be the following:

- Design and acceptance of the targeted programme 'Development of Single-Industry Towns of Russia' using the methodology of new industrial policy;

- Creation of an Agency for the Development of Russian Single-Industry Towns, an initiative justified by international and Russian practice. Setting up this Agency would send a signal to society as well as to Russian and international investors that the Russian government is committed to transforming single-industry towns in Russia; and

- Giving flagship status within the relevant federal programmes to some of the anchor projects in large and medium sized single-industry towns. The characteristic features of such projects should be their experimental and pilot nature aimed at fostering new specializations in the local economy and switching from the reproduction of the backbone enterprise to its development, extension, and diversification. It may be possible to consider new specializations such as green farming, production control (including in the backbone enterprise), energy efficiency projects, customized housebuilding, manufacturing of innovative construction materials, etc.

The ideology of new industrial policy envisages that these actions address the full range of a given town's economic specializations.

First, it is necessary to create a package of policies for towns in a crisis or relatively stable situation. A state of crisis requires immediate decisions to be taken by an operational body i.e. a specially created team for designing local development scenarios with the participation of the local community and experienced external consultants. Setting up mobile teams of experts who are able to act as crisis managers in different localities could be an important federal policy in this regard. Standard industrial policy solutions for single-industry towns, varying depending on the local unemployment rate or production level, have proven ineffective. Consultants may use a set of tools to develop new industries, including eco-industries, establish cultural facilities, etc. For example, the practices of large-scale acquisition of property, regulation of ownership relations, and establishing free land pools are often pursued to prevent the catastrophic degradation of urban infrastructure. Expanding existing local production may be beneficial; sometimes, organizing massive rotation schemes have proven a salvation. However, the specific actions for each town can only be customized and determined on-site in close cooperation with local communities, representatives of authorities and NGOs, as well as business. International practices in restructuring single-industry towns are also important to consider.

Communication with local communities must be prioritized early on, in the diagnostic stage. Crises in backbone enterprises are not always disastrous for a town's social and economic development. Sometimes, the local economy may have already adjusted to a new specialization. For example, Umyot settlement in Mordovia Republic, long included in the list of single-industry settlements, has carved out a unique niche for itself as a supplier of food services for transit traffic on the Moscow - Samara route. In Värtsilä settlement, a weak backbone metalware enterprise continues alongside the expansion of promising industries such as timber processing and cross-border trade. Even more remarkable is the example of Chistye Bory settlement in Kostroma Region where a backbone nuclear power plant was never built but the local community continues working in the construction industry using a rotation scheme [Zausaeva, 2015].

As already noted, the success of a new industrial policy in the economic restructuring of a singleindustry town directly depends on the degree of local community involvement in the policy's design and implementation (representatives of the corporate sector, small businesses, municipal authorities, and experts). Regional offices of a specialized body, such as the federal Ministry of Industry and Trade, may be engaged in the day-to-day monitoring of the situation to be responsible for forming an anti-crisis team uniting representatives of emergency response teams and local stakeholders if the local situation significantly worsens.

Policy tools applicable to relatively stable single-industry towns may be divided into several categories: improving the urban infrastructure; developing the local political system and local community networking; support for educational institutions; and diversification of the local industrial system.

Urban environment and infrastructure. Mechanisms of reducing the costs of facilities maintenance play a critical role in a wide range of actions aimed at rehabilitating single-industry towns. These include fostering eco-industries (for example, using waste to generate electric or heat power has great potential 
for dozens of towns located in forested areas); implementing alternative sources of energy and smallscale power generation; improving energy performance (for example, construction of energy efficient buildings and residential areas in Zhatai settlement of Yakutia region). Russia's existing development institutions can help to implement the above mechanisms. However, a decisive role in Russia's current circumstances probably lies with removing institutional barriers, a role confirmed by the best Russian practices of municipal development.

Social and political environment. This is perhaps the hardest aspect of urban development to reform, which however usually produces the greatest effect. It primarily refers to establishing local small business associations and involving players into local programmes of social and youth entrepreneurship. We noted above that entrepreneurship and other network associations are most effective in coordinating the efforts of a local business community, and in representing its interests in interactions with other stakeholders, local and federal authorities, and development institutions.

Network initiatives may be centered on such unexpected activities as organizing volunteer work. Experience has proven that even traditional 'subbotniks', if organized informally, promote unity of different social groups and enhance activities that aim to solve pressing urban problems. More often than not, subbotniks encourage the emergence of teams that want to actively transform the urban environment, do grassroots strategic planning of local development, and act as a voice for the opinions of the urban community during negotiations with the administration of a backbone enterprise and the local authorities. Generally, volunteer activities require the involvement of social communications and modern urban development experts; therefore, co-financing through grants (or reimbursement of costs) for such experts' services may be an effective tool for the development of single-industry towns.

Knowledge infrastructure. This category of policies includes professional development and re-skilling programmes, as well as tailoring educational standards to the actual needs of local businesses. International experience of benchmarking development pathways of single-industry towns, where businesses take different positions in structures of parent holdings, shows that the presence of research and application mechanisms in the local industrial system are critically important. Local education institutions of all levels, which have recently been extensively downsized in Russia, have huge potential not only in professional training, but also in conducting research and development that aim to solve local problems and design innovative products customized for the specific urban economy or backbone enterprise (recycling, power saving, development of new products and services on the back of core products, etc.). Policies, for example, to encourage research and development, launch testing sites, and support small innovative companies are especially important in this regard.

Industrial system. Here we mean the search for technological processes that are different to those already used in the production chain, when it becomes possible to use new manufacturing methods, expand the product range, diversify the network of suppliers and consumers, and launch new spin-offs. It is practicable to establish new production runs, primarily based on innovative technologies, preferably with outside sources of financing (in particular, from development funds), and implement infrastructure projects (including the construction of new roads that literally open the way to new markets and suppliers for an enterprise).

An almost universal formula for economic recovery of a single-industry town is development of ecoindustry: recycling and reprocessing of industrial waste, secondary recycling and further recycling of mining industry products, heat and electric power generation using accumulated and current waste of timber-cutting, etc. In the long-term, one recommendation is to develop a federal targeted programme for eco-industry development in Russia, in which single-industry towns could be included as testing sites. Improving people's quality of life directly depends on manufacturing food products for the local market. Support from the state agricultural bank, Rosselkhozbank, which has been implementing agro-industrial projects in some single-industry towns (e.g. Pavlovo, Semiluki, and others), may prove effective.

Multi-sector industrial parks may represent a valuable way to support local business in single-industry cites that are centres of urban conglomerations (for example, Serov), as confirmed by a number of successfully implemented projects. Remote isolated towns require a different approach to rehabilitation, namely: an approach targeted to individual small and medium innovative enterprises, supporting specific focal points of economic growth, and setting up municipal technology parks that can ensure not so much high business efficiency and profitability for businesses as be a kind of 'safety cushion' for the local economy. The industrial system of such towns is characterized by a rigid production chain of the backbone enterprise, aggravated by geographical isolation that necessitates the search for very narrow production niches for recipients of support. The list of options for the more remote and isolated single-industry towns includes manufacturing equipment for small and medium companies located in other single-industry towns; making complete production lines for eco-industry enterprises; making innovative products for 
the agro-industrial complex, energy saving and construction materials; producing equipment and tools for modernizing the infrastructure of northern towns; use of alternative energy sources; design of new heat insulation materials, etc.

Thus, the ideology of such reorganization efforts must be based on designing production network structures uniting different single-industry towns. Activities aimed at supporting some single-industry towns may create demand for new industries in other similar towns, for example, in the process of modernizing the housing and utilities sector.

The nature of innovative search in single-industry towns is directly determined by the fundamental particularities of local communities. Nevertheless, however important this issue may be, it is not right to associate it exclusively with the issue of urban economy restructuring, as innovative potential has far greater scope. The demand for introducing the institutions and mechanisms of innovative search in single-industry towns is fueled by external factors. The best experiences of its implementation can and should be rolled out to other settlements with similar conditions. The ideas of innovative search may prove fruitful in many sectors and spheres of regional and municipal policy, which over time should be redirected towards creating the conditions for innovative activities for a maximum possible number of players.

This paper has been prepared based on [Zamyatina, Pilyasov, 2015].

\section{References}

Agrawal A., Cockburn I., Rosell C. (2010) Not Invented Here? Innovation in company towns. Journal of Urban Economics, vol. 67, pp. 78-89.

Anas A., Xiong K. (2005) The formation and growth of specialized cities: Efficiency without developers or Malthusian traps. Regional Science and Urban Economics, vol. 35, p. 445-470.

Audretsch D.B., Thurik A.R. (2001) What's new about the new economy? Sources of growth in the managed and entrepreneurial economies. Industrial and Corporate Change, vol. 10, no 1, pp. 267-315.

Bartik T.J. (2009) The Revitalization of Older Industrial Cities: A Review Essay of Retooling for Growth. Growth and Change, vol. 40, no 1, pp. 1-29.

BazEl (2013) Monogoroda. Perezagruzka. Poisk novykh modelei funktsionirovaniya monogorodov Rossii $v$ izmenivshikhsya ekonomicheskikh usloviyakh [Monocities. Restart. The search for new models of functioning of Russian single-industry towns in the changed economic conditions], Moscow: Bazovyi element (in Russian).

Caravelis M., Russell I. (2001) From Mining Community to Seasonal Visitor Destination: The Transformation of Sotiras, Thasos, Greece. European Planning Studies, vol. 9, no 2, pp.187-199.

Chirkova E. (2011) Kiruna. Metamorfozy monogoroda [Kiruna. Metamorphosis of a single-enterprise town]. Voprosy ekonomicheskoi i politicheskoi geografii zarubezhnykh stran, vol. 19, pp. 222-238 (in Russian).

CISRE (2012) Gorod posle kombinata. Sotsial'no-ekonomicheskie strategii zhitelei goroda Baikal'ska [City life after the plant closure. Socio-economic policies of Baikalsk residents], Irkutsk: CISRE (in Russian).

DawsonCity.Ca (n.d.) Dawson-city: official website. Available at: http://dawsoncity.ca/, accessed 22.12.2014.

Dvas G. (2009) «My tol'ko znaem, chto u „Rusala” net deneg...». Interv'yu s Grigoriem Dvasom, vitse-gubernatorom Leningradskoi oblasti [«We only know that "Rusal” has no money...». Interview with Gregory Dvas, vice-governor of the Leningrad region]. Kommersant, 01.06.2009. Available at: http://www.kommersant.ru/doc/1179661, accessed 25.09.2014 (in Russian).

Ekspert Severo-Zapad (2013) Sotsial'nyi biznes na yagodakh [Berrypicking-based social business]. Ekspert SeveroZapad, 14.10.2013. Available at: http://www.expertnw.ru/news/2013-10-14/sotsialny-biznes-na-yagodakh/, accessed 22.12.2014 (in Russian).

Ferman B. (1996) Challenging the Growth Machine. Neighborhood Politics in Chicago and Pittsburg, Lawrence: University Press of Kansas.

Gebauer A., Woon N.C., Parsche R. (2003) Regional Technology Policy and Factors Shaping Local Innovation Networks in Small German Cities, Munich: Ifo Institute for Economic Research.

Granovetter M. (1985) Economic action and social structure: the problem of embeddedness. The American Journal of Sociology, vol. 91, no 3, pp. 481-510.

Grigoriev M. (2006) Chto sluchilos'v Kondopoge? [What happened in Kondopoga?]. Ekspert [Expert], no 47 (541), 18.12.2006. Available at: http://expert.ru/expert/2006/47/chto_sluchilos_v_kondopoge/, accessed 25.09.2014 (in Russian).

Hassink R. (2005) How to Unlock Regional Economies from Path Dependency? From Learning Region to Learning Cluster. European Planning Studies, vol. 13, no 4, pp. 521-535.

Hausmann R., Rodrik D. (2002) Economic development as self-discovery (NBER Working Paper 8952), Cambridge, MA: NBER.

Hausmann R., Rodrik D., Sabel Charles F. (2007) Reconfiguring industrial policy: A framework with an application to South Africa (CID Working Paper no 168), Cambridge, MA: Harward University Press.

Hermann B. (2002) Political Economy of Modernising Old Industrial Areas and the Crisis of the New Economy - The Example of the Ruhr Area and the City of Dortmund. Paper presented to the 42nd European Regional Science Association Congress, Dortmund, 27-31.08.2002.

Humphrey C. (ed.) (2007) Urban Life in Post-Soviet Central Asia. London: UCL Press. 
Irkutsk Media (2014) Sezon klubniki v Irkutskoi oblasti: opytom vyrashchivaniya yagody podelilis' zhiteli Baikal'ska [Strawberry season in Irkutsk region: Baikalsk inhabitants shared the experience of growing berries]. IrkutskMedia. $R u, 22.07 .2014$. Available at: http://irkutskmedia.ru/news/oblast/22.07.2014/372304/sezon-klubniki-v-irkutskoyoblasti-opitom-viraschivaniya-yagodi-podelilis-zhiteli-b.html, accessed 15.07.2015 (in Russian).

Karelinform (2013) Dvorets iskusstv v Kondopoge sobirayutsya zakryt' [Palace of the Arts in Kondopoga are going to close]. Karelinform, 07.03.2013. Available at: http://karelinform.ru/?id=36549\#ixzz2yq4qaWU4, accessed 25.09.2014 (in Russian).

Kospine.Ru (n.d.) Kospine Furniture: official website. Available at: http://www.kospine.ru/o-kompanii.html, accessed 07.12 .2014

Lappo G.M. (2012) Goroda Rossii. Vzglyad geografa [Russian Cities. A Geographer's View], Moscow: Novyi Khronograf (in Russian).

Lee D. (2007) Bilbao: 10 Years later. The New York Times, 23.09.2007. Available at: http://www.nytimes.com/2007/09/23/ travel/23bilbao.html?em\&ex=1190606400\&en=898bb5be11939f56\&ei=5087\%250A\&_r=0, accessed 22.12.2014.

LKAB (n.d.) Focus areas / LKAB's Strategy/Future // LKAB: official website. Available at: http://www.lkab.com/en/ Future/LKAB-Strategy/Focus-areas/, accessed 12.12.2014.

Lyubovnyi V.Ya. (2013) Goroda Rossii. Alternativy razvitiya $i$ upravleniya [Russian Cities. Alternatives for development and management], Moscow: Ekon-inform (in Russian).

Maier G., Trippl M. (2011) New Path Creation in Old Industrial Regions. The Case of the Software Park Hagenberg in the Province of Upper Austria. Paper prepared for the 51st European Congress of the Regional Science Association International, 30.08-03.09.2011, Barcelona, Spain.

North D. (2005) Understanding the Process of Economic Change, Princeton, N.J.: Princeton University Press.

Novikova L. (2014) KostomuShKi bol'she ne budet [KostomuShKa no longer]. 64th Parallel online, 11.11.2014. Available at: http://64parallel.ru/gorod/kostomushki-bolshe-ne-budet/, accessed 20.12.2014 (in Russian).

Popov V. (2007) Chto proizoshlo v Kondopoge? [What happened in Kondopoga?]. Available at: http://www.rusrepublic. ru/kond.html, accessed 25.09.2014 (in Russian).

P'yankova S.G. (2011) Formirovanie institutov razvitiya monoprofil'nykh territorii: zarubezhnyi i otechestvennyi opyt [Formation of single-industry areas of development institutions: foreign and domestic experience]. Ekonomicheskie nauki [Economic Sciences], no 12, pp. 422-427 (in Russian).

Pytkin A. N., Zagoruiko I. Yu. (2011) Kontseptual'nye aspekty reformirovaniya promyshlennykh monogorodov [Conceptual aspects of reforming industrial monocities]. Vestnik Chelyabinskogo gosudarstvennogo universiteta [Herald of Chelyabinsk State University], no 6 (221), Ekonomika [Economics series], issue 31, pp. 83-86 (in Russian).

RKS Group (2013) V fokuse Kostomukshi - pokupka firmy "Karkhatek" ukrepila pozitsii kontserna [Kostomuksha's focus - Acquisition of "Karhatek" strengthened the position of the Group]. Available at: https://pkcable.com/ vpered-k-budushemu/55-v-fokuse-kostomukshi-pokupka-firmy-karhatek-ukrepila-pozicii-koncerna.html, accessed 21.06.2015 (in Russian).

Rodrik D. (2004) Industrial policy for the twenty-first century, Cambridge, MA: Harvard University.

Rodrik D. (2008) Industrial policy: Don't ask why, ask how. Middle East Development Journal, demo issue, pp. 1-29.

Rodrik D. (2014) Green Industrial policy. Oxford Review of Economic Policy, vol. 30, no 3, pp. 469-491.

Starodubrovskaya I. (ed.) (2011) Strategii razvitiya staropromyshlennykh gorodov: mezhdunarodnyi opyt i perspektivy $v$ Rossii [Development Strategy of the old industrial cities: international experience and prospects in Russia], Moscow: Gaidar Institute (in Russian).

Todtling F., Trippl M. (2004) Like Phoenix from the Ashes? The Renewal of Clusters in Old Industrial Areas. Urban Studies, vol. 41, no 5/6, pp. 1175-1195.

Tötzer T., Gigler U. (2005) Managing urban dynamics in old industrial cities: Lessons learned on revitalising inner-city industrial sites in six European case studies. Paper presented at the 45th Congress of the European Regional Science Association - Land Use and Water Management in a Sustainable Network Society, 23-27.08.2005, Amsterdam.

Trippl M., Otto A. (2009) How to turn the fate of old industrial areas: A comparison of cluster-based renewal processes in Styria and the Saarland. Environment and Planning A, vol. 41, pp.1217-1233.

Trukhanova E. (2013) Predprinimateli otremontirovali most [Entrepreneurs repaired the bridge]. Rossiiskaya gazeta, 18.01.2013. Available at: http://www.rg.ru/2013/01/18/reg-cfo/most.html, accessed 25.09.2014 (in Russian).

Turkov A.V. (ed.) (2012) Razvitie monoprofilnykh naselennykh punktov v Rossiiskoi Federatsii: sbornik nauchnykh trudov [The development of single-industry settlements in the Russian Federation: The collection of scientific papers], Moscow: Financial University (in Russian).

Uskova T.V., Iogman L.G., Tkachuk S.N., Nesterov A.N., Litvinova N.Yu. (2012) Monogorod: upravlenie razvitiem [Single-industry towns: Management of development], Vologda: ISEDT RAS (in Russian).

VSU (2013) Problemy i perspektivy razvitiya monogorodov: materialy regional'nogo nauchno-prakticheskogo seminara [Problems and prospects of development of single-industry towns: Materials of regional scientific-practical seminar], Voronezh: Voronezh State University (in Russian).

Zamyatina N.Yu., Pilyasov A.N. (2013) Rossiya, kotoruyu my obreli: issleduya prostranstvo na mikrourovne [Russia, which we have found: Exploring space at a micro level], Moscow: Novyi Khronograf (in Russian).

Zamyatina N.Yu., Pilyasov A.N. (2015) Innovatsionnyi poisk v monoprofilnykh gorodakh: blokirovki razvitiya, novaya promyshlennaya politika i plan deistvii [Innovative search in single-industry towns: the lock-in of new industry policy and a plan of action], Moscow: LENAND (in Russian).

Zausaeva Ya.D. (2015) Institutsional'nye faktory razvitiya nesostoyavshikhsya atomnykh gorodov [Institutional factors of failed nuclear cities]. Demoscope Weekly, no 631-632, 23.02 - 08.03.2015. Available at: http://demoscope. $\mathrm{ru}$ /weekly/2015/0631/analit04.php, accessed 15.07.2015 (in Russian).

Zubarevich N.V. (2010) Regiony Rossii: neravenstvo, krizis, modernizatsiya [Regions of Russia: The inequality crisis, modernization], Moscow: Independent Institute for Social Policy (in Russian). 